\title{
耐風安定，抬散等に対する風洞の利用についで \\ On Application of a Wind Tunnel to Aerodynamic Stability and Diffusion
}

\author{
鉒口展宏** \\ Nobuhiro UKEGUCHI
}

最近，経斎の高度成長により生産設備の巨大化，交 通機関の高速化等が行われ，また反面その歪みとして 各種公害問题が潹刻化して来た，この上うな社会的背 景の中で安全, 信頼性, 無公害等の要求が高まって来 たため最近これらの諸問題の解決のために風洞を用い る研究が多方面で行われることになって来た。この中 で我々が風洞を利用して研究を行っている代表的例を ご紹介致したい。

\section{1. 耐風安定}

1.1 構造物の耐風安定性と風 洞利 用 自然風の中 で影響を受ける構造物は多種多様であり，耐風安定の 問題点もそれぞれの構造物によって異なってくる.し 加し基本的な研究の流れは変わらず，一般的に第 1 図 に示す流れに従って研究を進めている.

静的風荷量は構造物の基本的な風荷重であるからほ とんどの構造物で計測している. 非定常空気力は構造 物汃振動状態において作用する風荷重であり，振動の 源になる重要な風荷重である. てれは構造物の模型を 外部より加振させて強制振動状態で模型に作用する空 気力を計測している，模型が静止状態にあってもカル マン瀜等により振動的な空気力が生ずるが，てれを振 動空気力と考えて模型に加わる空気力を計椡してい る. 構造物汇乱れた風が作用すると乱れ炕よる空気力 あ生ずる. これに関しては風洞中に翼列を設置し，正 弦波変動風を作成して空気力を計測している.

以上が構造物に加わる空気力であるが，てれらを基 にして構造物の振動応答特性による振動性状を計算 し，一方では振動性状試験を行い理論と実験の比較㭘
討を行っている，また構造物全体の振動の場合は振動 にも空気力にも空間的な広がりがあるので空間モード を考虑した理論計算を行い，一方では全体の弾性模型 を用いて振動性状試験を行い，比較検討を行って実機 への応用を計っている.

振動性状試験では構造物の振動特性之空気力の相似 則を満足させる必要があるが，中にはどうしても相似 則を満すととが出来ない場合があ゙る（例えば吊橋の 架設中等) このような場合は模型の振動特性を使って 理論之実験の比較を行い,，理論のチェックをした後実 機の振動特性を使って理論推定を行い，実機への応用 を計っている.

前述のように構造は多種であるから物によって多少 問題のポイントが異る場合あある.以下それぞれの構

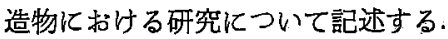

1.2 煙突 円柱の細長い構造物であるから暴風時 の静的な風荷重と季節風等で起とるカルマン渻による 振動が主な問題となる，自然風は地表面からの高さに より速度が異なるので，煙突の設計にあたってはそれ ぞれの高さによる風荷重を求める必要が生ずる。した がって洷突の場合の静的な風荷重は煙突の一部を切り 出した部分模型により各高さの部分に作用する空気力 を計測している．またカルマン渦による振動はカルマ ン渦の空間相関が問題となるので出来る限り全体模型 で振動実験を行なっている．第 2 図仙示す模型は全体 の剛体模型で基部をピン支持にし，上部より吊り下げ て端部をスプリングで支持して振動系を構成し，風洞 実験を行った例である．煙突関係で一ばん問題になる のが $R$ ，数の影響である. 何本加組み合わせた集合洷

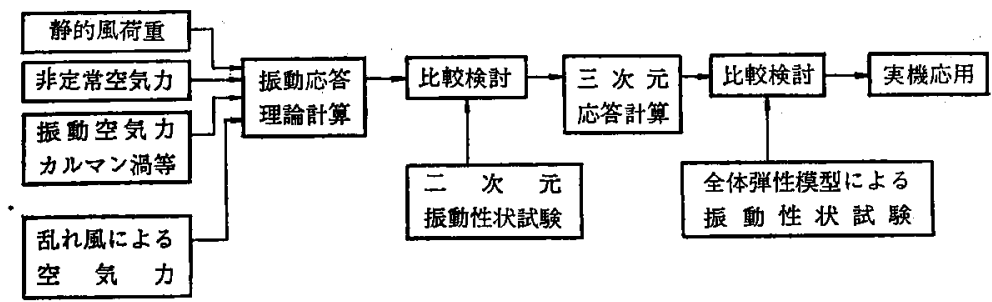

第 1 図 耐風安定性の研究フロー・チャート

\footnotetext{
* 昭和 49 年 3 月 5 日原稿受理

** 三菱重工業株式会社長崎研究所
} 


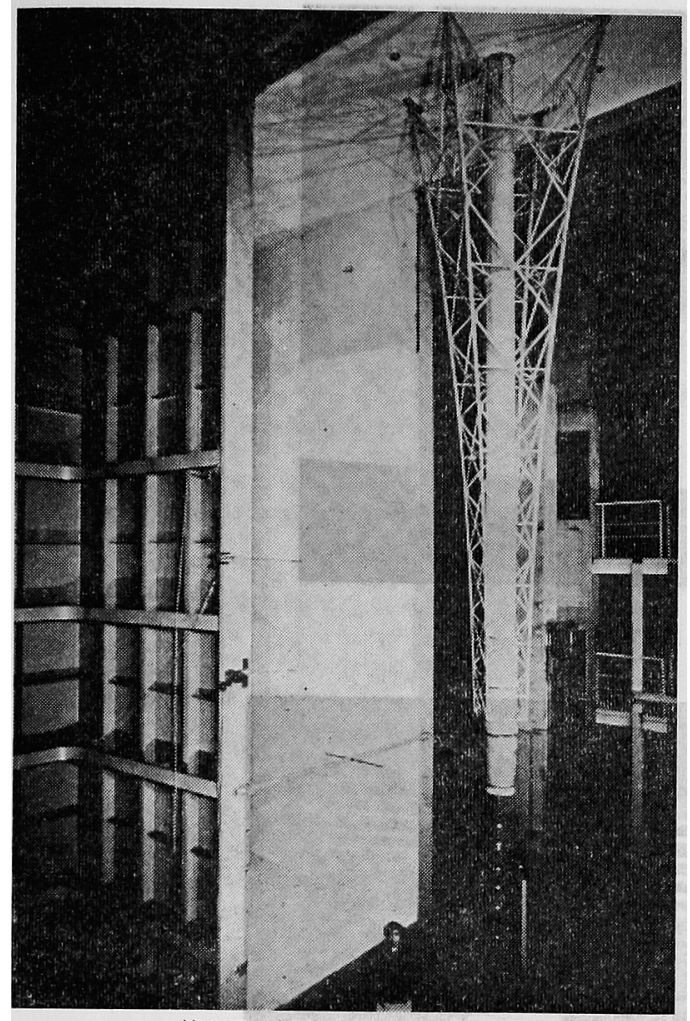

第 2 図振動試験用煙突模型

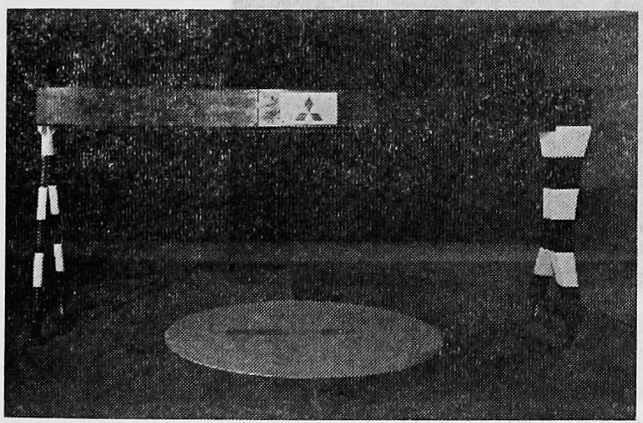

第 3 図振動試験用クレーン模型

突では $R$ 数の影響は比較的に少いようであるが，高 $R$ 。数領域では未知の面が多い，これに関しては実機 の煖突を対象代研究を進めていく予定である．なお力

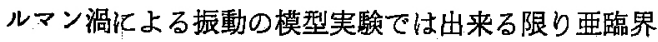
$R_{\varepsilon}$ 数領域で研究を進めている。

1.3 クレーン 各風向に抢ける静的 6 分力風荷重 とカルマン渦による振動が問題となる．静的風荷重は 㔄体模型を使用し， 6 分力試験を行い，カルマン渦に よる振動は部分模型による空気力の計測，振動性状試 験を行い理論検討を行うと同時に全体の空弾模型（第 3図）による振動性状式験を行った．またクレーンの

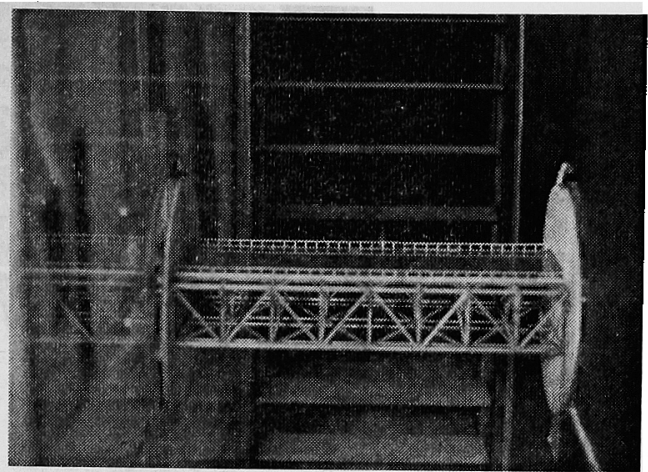

第 4 図 翼列と吊橋模型

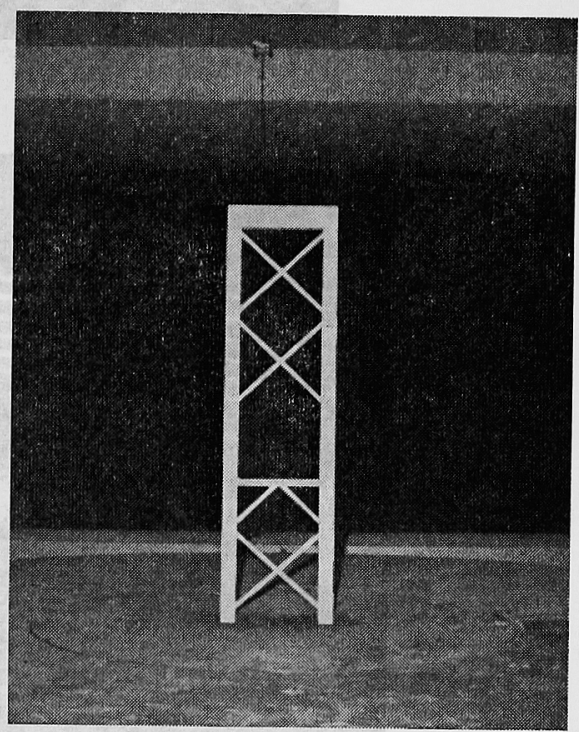

第 5 図吊橋タワー

振動は風の乱れが大きな要因になるととが判ったので クレーン建設地形模型に上り風速分布之乱れを計測 し，乱机による振動性状試験も合わ甘て行った。

1.4 橋梁 橋梁関係ではフラッター，乱れによる バフェッチング，カルマン渦による振動等多種の振動 が起こる. との中でフラッターに関しては非定常空気 力の計測，二次元，三次元振動性状試験之理論計算を 比較して研究を進めている. カルマン渦による振動も 同様な方法で研究を進めているが，乙の種の振動では 特に構造减衰率を加え振動性状試駼を行い，空気力の 非線形性を重点に研究を進めている. 変動風（乱れ） による振動む大きな問題となっており，ての種の研究 では風洞中に翼列（第 4 因）を設置し，正弦波変動風 を作成して変動空気力の計測，理論計算，変動風中の 振動性状試験（第 4 図）を行い，振動現象を究明して いる.

1.5 吊橋タワー カルマン渦による振動が主な問 

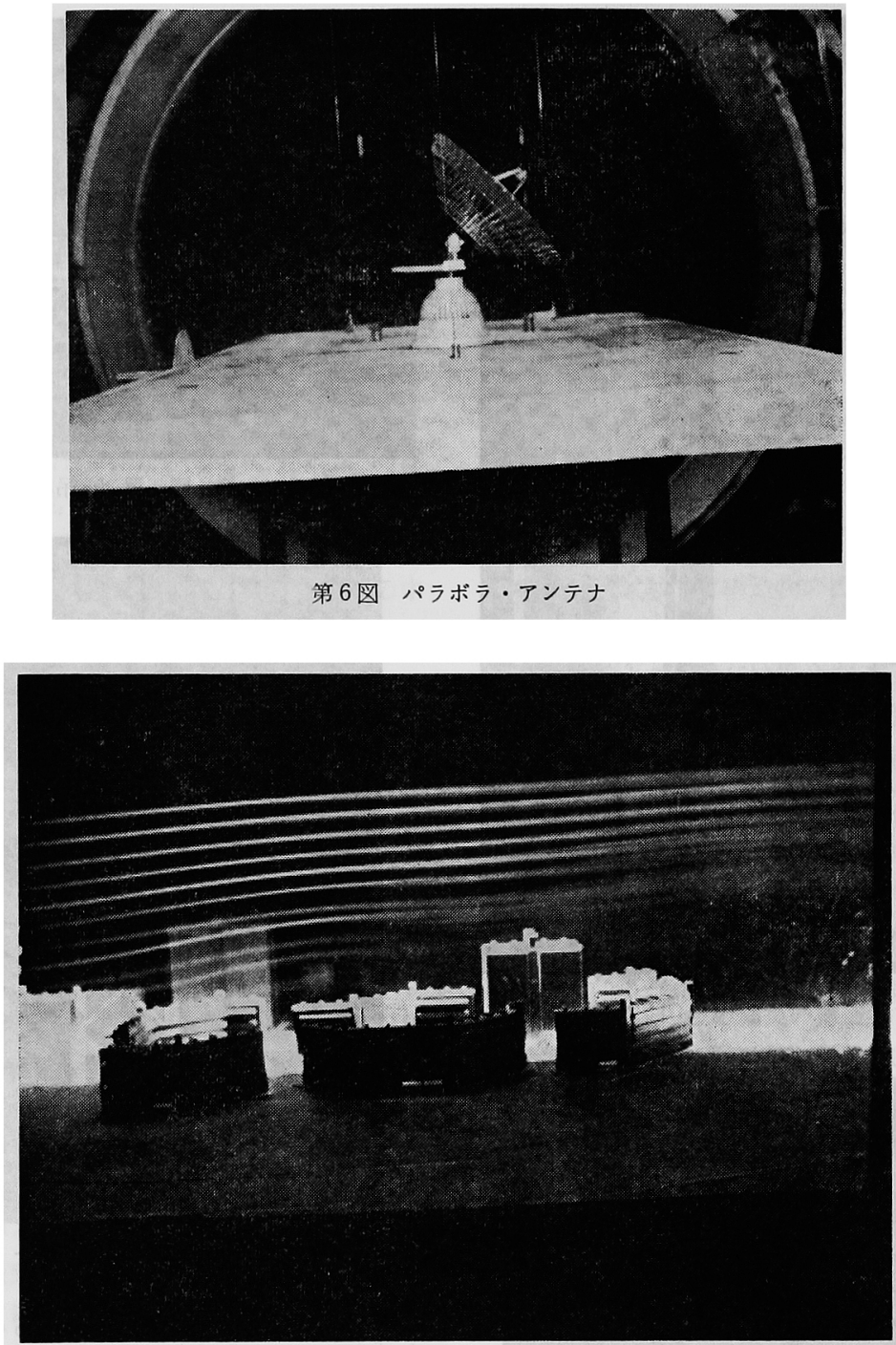

第7図高虽 住 宅

題であるので，二次元剛体模型に上る空気力の計測と 全体の空弾模型に上る振動性状試験により，本問題を 究明している. カルマン渦によって生ずる空気力は構 造物の振動振幅に対し必ずしあ線形の関係にないの で，振動性状試験では特に構造減哀量を変えて振動性 状の変化を重点に研究を進めている，また防振装置も 重要な課題の一つであるが，てれについては主塔の囲 りにカウリングを取付けて防振を計る方法を見い出し た.

1.6 パラボラ・アンテナ 静的な風荷重では 6 分 力の静的風荷重, 鏡面内の圧力分布, 振動関係ではパ ラボラ鏡面内のパネル振動が問題となる。パネル振動 に関しては変動圧力ピックアップにより振動的な圧力 をパラボラ表面わよび異面で計測し，スペクトル解析
により究明している.

1.7 高層住宅 静的な転倒モーメント，各部の風 圧力，周辺気流等の問題がある. このために静的 6 分 力の試験，圧力分布計測を行なっているが，特に周辺 気流の問題では系の流れによる可視化，煙の流れによ る可視化を中心汧究を進めている。

1.8 電波中継塔 上半身が海上に，下半身が海中 に浸る構造物で風および海流に上る漂流，およびかル マン渦に上る掁動が考えられる.したがって海上部拉 よび海中部に分け荷重計測および振動性状の試医を行 っている

1.9 ドック上屋 ドック上に取付けられる移動式 の建屋で静的 6 分力の風荷重と屋根部䲉く圧力が問 题となる．特に屋根下に建造ブロックがある場合，な 


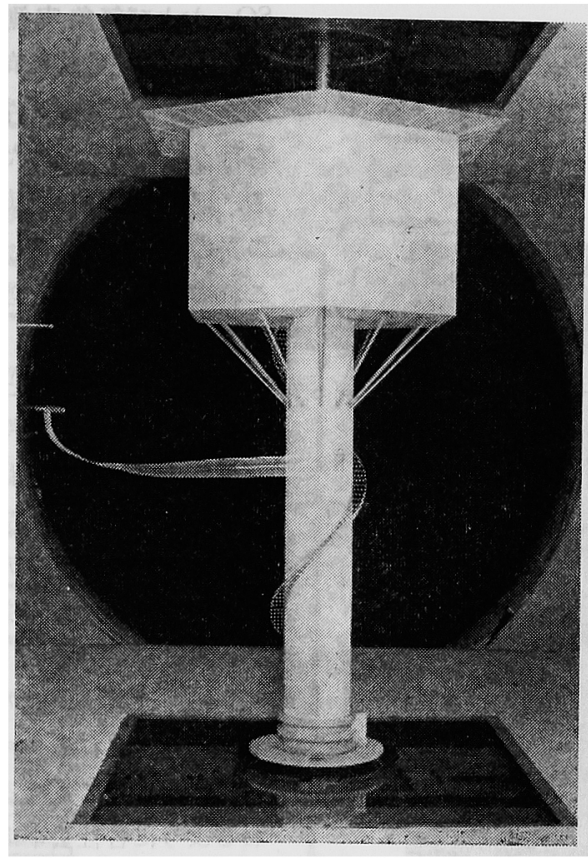

第 8 図 電波中継塔

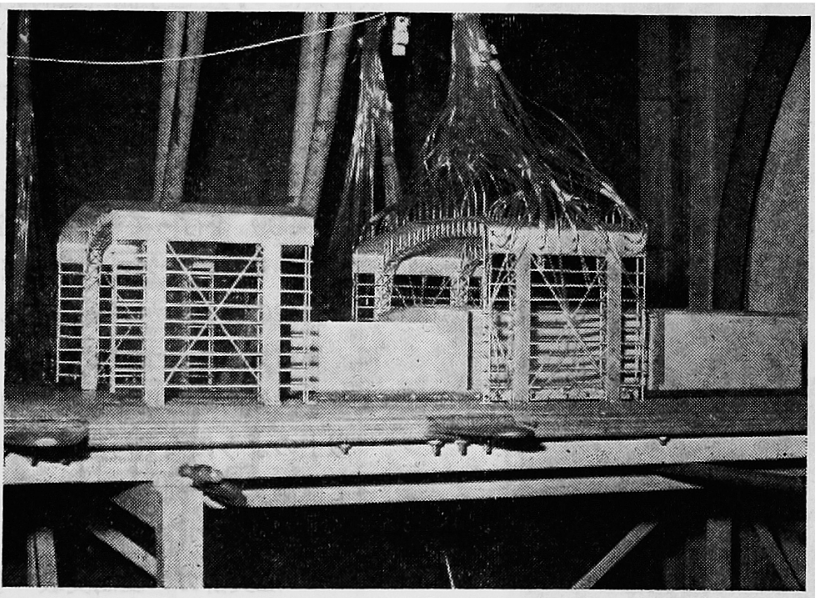

第 9 図ドック上屋

い場合についての風荷重を究明している.

1.10 船舶 漂水の浅い船舶では風荷重が安定性, 操従性に大きな影響を与える。したがって各風向から 受ける静的 6 分力を計测して問題を究明している.

\section{2. 拡散}

2.1 大気污染と風洞利用 産業と都市の著しい発 展にともない，大気污染は深刻な社会問題となってい る. この大気污染の防止には，(1)燃料中の污染質の除 去，(2)排ガス中の污染質の除去，(3)然焼法の改善，等 を実施して大気中に污染質を全く排出しないととが理
想的であろうが，現実的には不可能である.したがっ て，(4)污染質の大気拡散法の改善，(5)既設，新設を含 めた産業・都市立地の見直し，等をも含めた広範多岐 にわたる検討の中から，環境污染濃度が許容レベル以 下になるような対策を組立てるのが現実的な考え方と なる.そのために，大気中に排出された污染質の挙動 々環境污染濃度を把握（予測）することが是非とも必 要になる. この污染予測による大気污染防止の進め方 の概略は，(1)現状分析，(2)将来予測，(3)改善，(4)アフ ター・ケアの順序によって行うことになる.

（1）現状分析 当該地域における過去何年間かの 


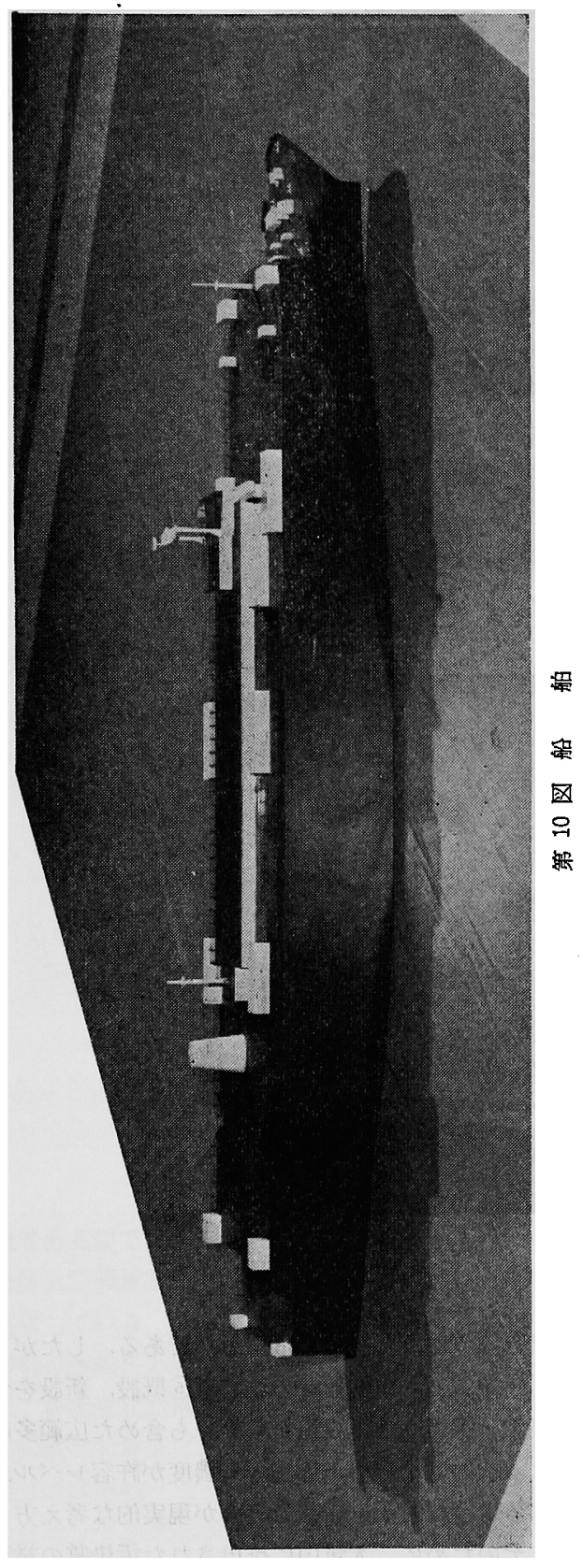

$\mathrm{SO}_{2}$, および気象実測データを分類し，高濃度出現時 の気像条件（危険風向，危険風速）を統計的に求的， 別途調查した煙源条件を用いて，乙の場合の現状予測 を行う．ての予測のために一般に風洞実験が実施され る. 現状予測結果と実測値との比較により，予測結果 の妄当性を吟味して，予測手法の正合性を確認する。 これにより発生源 (煙源) の変百による将来予測と改 善予測が可能となる.すすなわち予測手段としての風洞 実験が利用できるここになる。

（2）将来予測，将来の工場でとの最条設備計画 （最終の煙源条件）扔よび当該地区における工場配置 計画を全て調査し，将来煙源条件を決め(工場進出末 定地区があれば，モデル・プラント案を立てる)，現 状予測を行ったと同様にして，将来予測（風洞実験） を行う.

（3）改善 一般に将来予測された污染濃度は環境 基準で許容されるレベル以上のものが多いので，これ を許容レベルに下げる必要がある.許容レベルを下ま わるように各社公平に 1 社当たりの割当濃度を決め, 各社は, 割当竖度以下になるように煙源の改善を行い， 改善案についての予測（風洞実験）を行って，環境基 準の満足を確認し，最終案を決定する。

（4）アフター・ケヤ 各社每经年計画（煙源） に基づき，達成すべき期間内はもちろんのとと，それ 以後においてす環境基淘を満足できるまで，経年予測 （風洞実験）を行って経年計画を改良して行く，一方 モニターリング・システムを完備し，経年予測と比較 して多少の見直しが必要であれば補正を行うと同時 に, 異常気象には予報警報システムとの組み合わせに より，大気污染防止に万全を期す.

以上の上うに大気污染防止のための予測を行うに当 って風洞実験が利用され，作業段階に応じてその利用 の目的む異っている.

2.2 煙突排ガス風洞実験 予测のために用いられ ている煙㹡散風洞の一つを下图に示す.

煙乫排ガスの大気拡散を風洞内に再現するので，こ の種の風洞の測定室は風下にかなり長いのが特徵であ り，風洞気流の乱流条件之風速分布（境界層）を制御 する装置が付いている，予湘実験を行うために相似㑡 に関する基䃈研究を初めとして, 乱流制御, 乱流境界 層，排煙上昇，排煙拡散等に関する種々の基礎研究が 予め必要となる. とのために風洞実験で排煙の挙動お よび抎散を調查する次のような実験が行われている. (1)煙流実験，(2)乱流域観湘実験，(3)流線観湘実験，(4) 系流実験，(5)気流乱记計測実験，(6)定性 (変色) 実験, (7)定量実験，(1) （4)は挔散現象の補助的観測法，(5)は 㹡散現象の解析上必要な資料の測定法であり, 最も有 


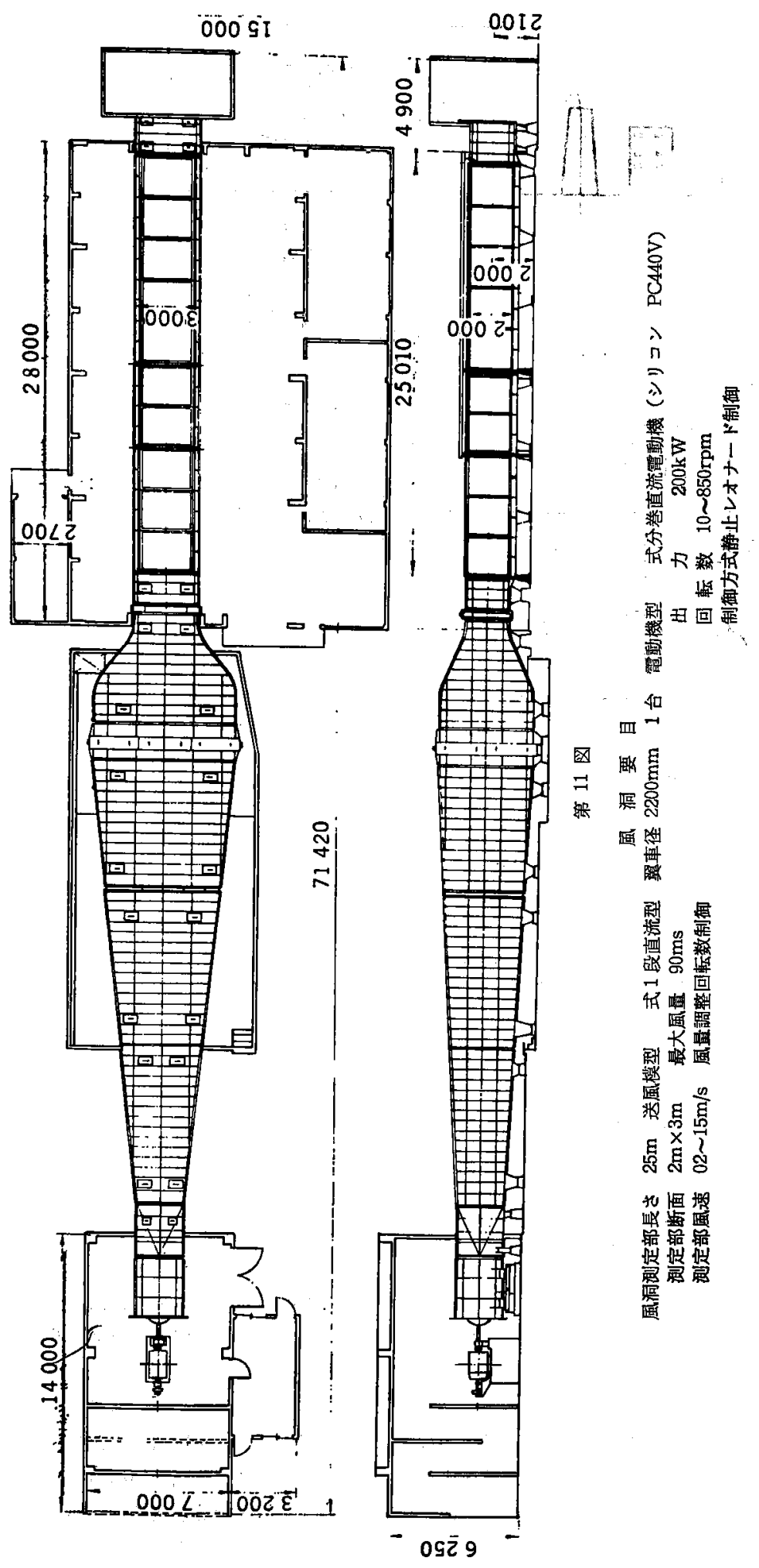


WIND TUNNEL TEST SECTION

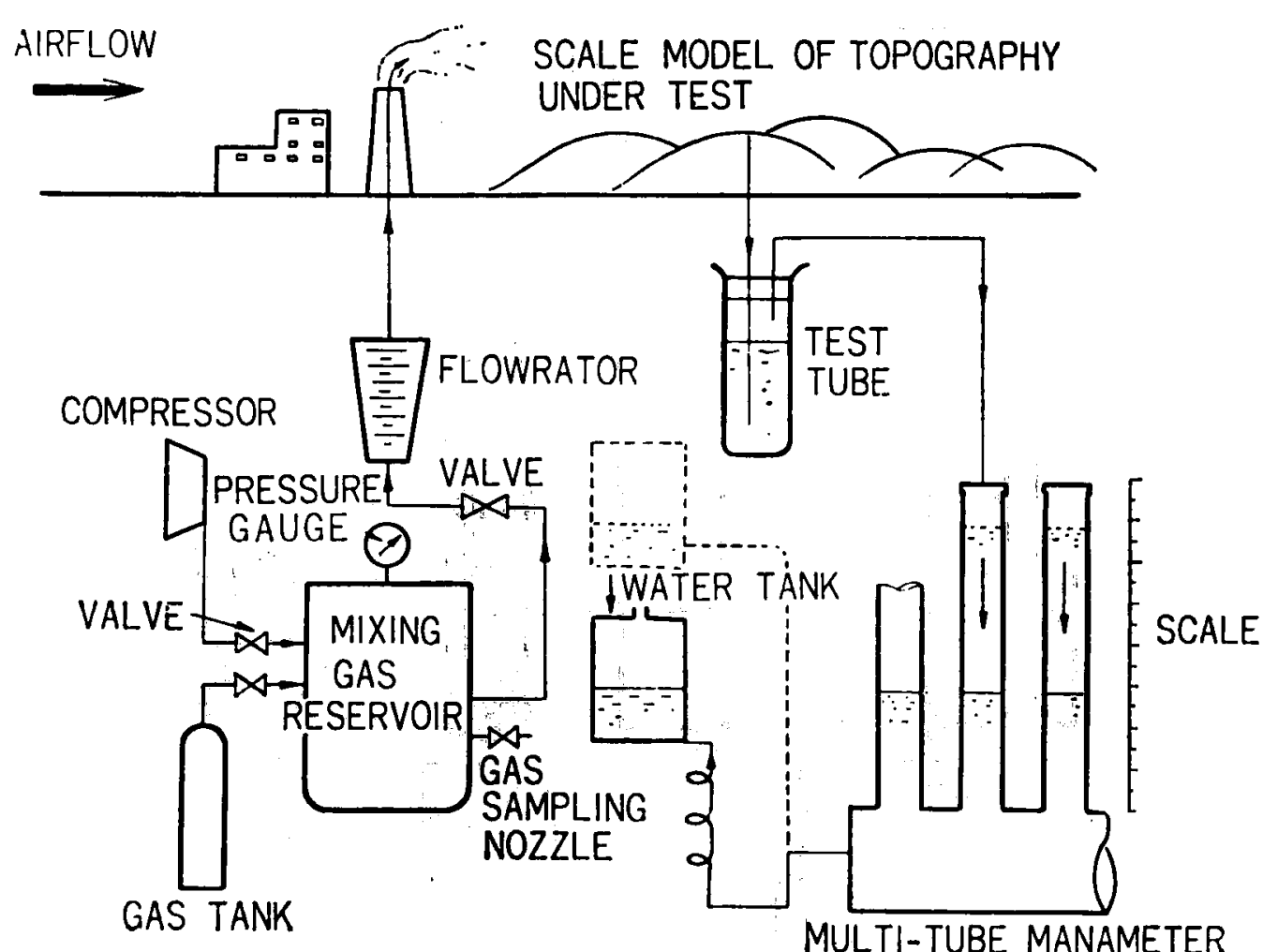

第 12 図 定罵实験サンプリング法

用なあのは(6)，(7)の方法である，予湘に用いられるす のは，特に(7)であり, 地上および空中濃度を定量的に 測定するもので，概略を次図に示す。煙乫一本の地上 濃度分布を $C_{p}$ とすると, 工場 $\mathrm{A} の ~ n$ 本による地上濃 度分布の重合，つまりA工場の地上濃度分布は

$$
n \text { 本 } C \text {. }
$$

となる. このようにして, 当該地域全体の全工場数 $N$ による全重合濃度分布は,

$$
\sum_{\text {地場 }} \sum_{\mathrm{A} \text { 工域 }}^{n} C_{p}
$$

となる.この結果が予測結果であり試験時の煙源が現 状煙源であれば，現状予測となるなお；煙突につい ては，ダウン・ウオッシュ，ダウン・ドラフトの防止 および煙突排煙間の干涉問題, 吐出口の改善, 集煙法 についての試験も行われている. 風洞実験法と実験結 果の詳細にていては，参考文献を参照願いたい.

2.3 その他の風洞実験 大気中へガス状廃曩物を 放出する設備は煙实のほかにもいろいろな設備があ
る. これらの対象に応じて風洞実験内容は少々変わっ てくるが; 払散風洞の利用法の概略は，2.11で述へ たのとほほ同じであるので，主なる応用事例について 以下まとめた。

(1)道路上におりる自動車排出ガスの搪散……自動車 排出ガスによる道路周辺の污染状況の諴查，特に道路 檴造と周辺の地形・地物との干涉による排気ガスの㹡 散調查に風洞実験が利用されている。

(2)クーリングタワー排気㹡散……温排水公害を防止 するためにクーリング・タワーが採用される傾向にあ る.とのクーリング・タワー一ら排出される温排気の 地上影響，周辺建物，特に煙突（排煙）との干涉，吸 排気の自己再循環，複数クーyング・タワーがある場 合の相互干渉等が調査問題となる.

(3)原子力設備加ら排出される放射性物質の拡散

（4）トンネル坑口，または排気塔からの排ガス拡散 ならびに吸排気問題の検討

(5)ビル暖房等による煙害の検討

(6)舶用煙突による煙害・排煙ガス熱害等の検討 


\section{参考 文 献}

1）鉒口展宏，坂田弘：吊橋の耐風性江関する基硞研觉， 航空学会誌 Vol. 13, No. 133 号.

2）鉒口展広，坂田弘：吊橋の耐風性化関する基喽研劣 (続報), 航空学会誌, Vol. 14; No. 145 号.

3）坂田弘：溥翼の失速城に捃りる非定常空気力に関する 一考察, 航空学会誌, Vol. 18, No. 193 号.

4) N. Ukeguchi, H. Sakata, H. Tanaka : Oscillation of Cylindrical Stucture IABSE International Association 9 the Congress.

5) H. Tanaka, S. Takahara: Study on Unsteady Aerodynamic Forces acting on an Osrillating Cylinder. Proc. 19the Japan Cong. for Applied Mech. 1969.

6) 鉒口展宏, 坂田弘：パイプ・アーチ橋の風压抵抗閉 す万風洞実験, 三落テクニカル・ブリテン MTB 010022 .

7) 三药重工技報 (橋梁特集号) 第 3 巻，第 6 号.

8) 三蒙重工技報（橋梁特集号）第 7 巻, 第 7 号.

9) Ukeguch, N., Sakata, H. Okamoto, H. and Y. IDE, 1967: Study on Stack Gas Diffusion, Mitsubishi Technical Bulletion, No. 56, MHI.

10）鉒口展宏 : 1967, 煙拡散们関する風洞実験, 航空学会 誌, 15 巻 167 号, 417-425.
11) Ukeguch N. Sakata, H. and Y. Ide: 1968: Turbulent Diffusion in a Turbulent Boundary Layer. 10the Midwestern Mechanics Conference (1967/8), Developments in Mechanics Vol. 4.

12）鉒口展宏，坂田弘，井手靖焳，1968：乱流境界層を考 慮した乱流拡散, 航空学会誌, 16 巻, 168 号 16-22.

13) Ukeguchr, N. and Y. Ide, 1968: Turbulent Diffusion in a Turbulent Boundary Layer, Proc. 18th Japan Nat. Cong. App. mech. 145-153.

14）筌口展宏, 倉崎六夫, 松本考良: 建物の乱流域低減法, 三菱重工技報，Vol，3，No. 4 .

15) Ukeguchi, $N$. and $Y$. IDE, 1970: Structure for Atmospheric Diffusion and Ground Level Concentration, Proc. 19th Japan Nat. Cong App. Mech. 157-162.

16) Uкeguchi, J., Окамото, H. and Y, DE 1970: Wind Tunnel Experiments on Exhausted Gas Diffusion with Thermal Elevation, Second Int. Clean Air Cong. Int. Union. Air Poll. Cont. Ass. (Dec).

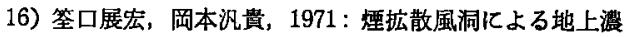
度予測法の開発，三菱重工技報，Vol，18，No. 2，179 $-187$.

17）鉒口展宏，1971：工場排ガスの拉散について，機械学 会誌，74卷626号，28-34.

\section{農 業と風 洞 実 験*}

\section{Agriculture and Wind Tunnel Experiment}

井上篓 一**

Eiichi Inove
農業は風の中で行なわれている，風の吹かない密室 の中では植物は生育するととができないであるう，そ てで作物の生育と風との関係を調へるととが農業気象 学という学問の中の一つの大きな分野となっていて, 作物の風洞実験というととがしばしば行なわれる.

航空機や建築物などとちがって一般に作物は模型に 作るというわけにはいかない。なぜならば作物は生き ているからである．しかし幸いにす作物はそれほど大 きくあないしそれ代当たる風の速さもせいぜい毎秒数 十メートルの程度であるから，作物を入れて風を吹か せる風洞はできないととではない．

問題になるのは風洞の中の気流が自然の風之同じあ のであるかどうかということと，風洞の大きさの制限 によって僅かな数しか入れられない作物の風洞気流に 対する応答が広い田围や畑传っている作物の自然の 風に対する応答と同じものであるとは言えないことで ある.

私は東大の航空学科で教育を受け, 風洞実験につい ての初めての教えを受けた. Reynolds 数というとと

* 昭和 49 年 3 月 5 日原稿受理

**㤟業技術研究所 気象科
も教わった．むはや 30 年以上も前のととである.

そのころには流体力学の相似法則というすのがあ って，風洞実験をやるときにはその現象についての Reynolds 数を同じにしなければならないというふう に教わった．つまり同じ空気の中で起こる現象を風洞 の中の模型で再現するためには，模型の大きさを 10 分の1にしたならば空気の流れる速さを 10 倍にしな ければいけないということである.

てんなととをいうようになったのは，流れが層流か ら乱流に移り変るときに Reynolds 数が一定であると いう知識があったからである. Reynolds 数 $R$ という のは周知のでとく

$$
R=U L / \nu
$$

で定義されている，Uは速さ，Lは長さ，注流体の分 子動粘性係数である.同じ空気という流体ならばその 動粘性係数のレには変わりはないであろうから, 翼幅 $10 \mathrm{~m}$ の飛行機という $L$ のあのが毎秒 $100 \mathrm{~m}$ という 速さで大気の中を飛ふ様子を 100 分の 1 の大きさの $10 \mathrm{~cm}$ という $L$ を持った模型を風洞の中の気流に入 れて調べるためには風洞気流の $U$ を每悡 $100 \mathrm{~m}$ の 100 倍，つまり毎少 10,000 $\mathrm{m}$ にしなければいけないとい 